Article

\title{
Rebuilding Trust in Broken Systems? Populist Party Success and Citizens' Trust in Democratic Institutions
}

\author{
Marlene Mauk \\ Department of Knowledge Transfer, GESIS—Leibniz Institute for the Social Sciences, 50667 Cologne, Germany; \\ E-Mail: marlene.mauk@gesis.org
}

Submitted: 11 February 2020 | Accepted: 20 April 2020 | Published: 17 July 2020

\begin{abstract}
What effect does the recent rise of populist parties harnessing an anti-system rhetoric have on political trust? Will citizens become disenchanted with and lose trust in the political system, or could populist party success even stimulate a growth of political trust? Arguing that populist parties may well be conceived as a corrective force giving voice to and addressing citizen concerns about the established political system, this contribution hypothesizes that populist party success will increase political trust among the general public, especially in countries lacking democratic quality, with weak corruption control, and meagre government performance. Empirically, it combines ParlGov data with survey data from the European Social Survey (2002-2016) as well as aggregate data from the Varieties-of-Democracy project and the World Development Indicators to investigate how political trust has changed in relation to the growing success of populist parties and how democratic quality, corruption control, and government performance have moderated this relationship in 23 European democracies. Its main findings indicate that, at least in the short run, political trust increases rather than decreases following populist party success and that this increase in trust is most pronounced in political systems that lack democratic quality, struggle with corruption, and deliver only meager government performance.
\end{abstract}

\section{Keywords}

corruption control; democratic quality; economic performance; government performance; political trust; populism

\section{Issue}

This article is part of the issue "Populism and Polarization: A Dual Threat to Europe's Liberal Democracies?" edited by Jonas Linde (University of Bergen, Norway), Marlene Mauk (GESIS - Leibniz Institute for the Social Sciences, Germany) and Heidi Schulze (GESIS-Leibniz Institute for the Social Sciences, Germany).

(C) 2020 by the author; licensee Cogitatio (Lisbon, Portugal). This article is licensed under a Creative Commons Attribution 4.0 International License (CC BY).

\section{Introduction}

Recent years have seen a new wave of populism across Europe. Both right-wing and left-wing populist parties have entered parliaments from Spain to Slovakia, and in some countries have even won ruling majorities. These developments have been unequivocally met with concerns, most importantly with regard to the consequences for the democratic political system (Galston, 2018; Puddington \& Roylance, 2017). In light of countries like Hungary and Poland, where populists in power have begun to dismantle the very core of liberal democracy, these fears seem far from unwarranted. From a political-culture perspective, one of the main concerns is that citizens may lose trust in the established democratic political system and its institutions. With previous contributions already finding a negative relationship between populism and political trust-voters of populist parties tend to be less trusting of the political system (Dahlberg \& Linde, 2017; Söderlund \& Kestilä-Kekkonen, 2009) and low levels of political trust tend to further voting for populist parties (Doyle, 2011; Hooghe, Marien, \& Pauwels, 2011; Rooduijn, 2018; Werts, Scheepers, \& Lubbers, 2012)-the recent rise of populism does not bode well for Europe's democracies. Yet, others have pointed out the potentially healing effect of populism: With new parties that challenge the establishment entering the political stage, citizens formerly disappointed 
by and disenchanted with politics may reconcile with the democratic system (Haugsgjerd, 2019; Mudde \& Rovira Kaltwasser, 2012). This seems particularly likely in democracies which leave a lot to be desired in the eyes of citizens. In countries where democratic quality is deficient, corruption rampant, and government performance altogether meager, populist parties can easily stylize themselves - and indeed be conceived by citizensas saviors come to mend a broken system.

Literature on the relationship between populist party success and political trust is scarce. While prior research has studied a myriad of sources of political trust (for an overview, see Martini \& Quaranta, 2020), the rise of populist parties or the national party system more generally has not yet received much attention as a source of political trust. Likewise, while scholarship on populist parties has investigated a broad number of issues including the relationship between voting for a populist party and political trust (e.g., Hooghe et al., 2011; Söderlund \& Kestilä-Kekkonen, 2009), it has yet to explore the consequences of the (system-level) rise of populist parties for political trust among the general public. Regarding the consequences of these macro-level developments, scholars have begun studying how populism affects liberal democracy (e.g., Biard, Bernhard, \& Betz, 2019; Mudde \& Rovira Kaltwasser, 2012; Müller, 2016). Yet the majority of them have focused on the impact populist parties have on actual policies and the quality of democracy, disregarding any effects on the attitudes of ordinary citizens. The only exception is a recent contribution by Haugsgjerd (2019), who demonstrates that supporters of the Norwegian radical-right populist Fremskrittspartiet have expressed increasing satisfaction with democracy after the party had gained executive power in 2013. Adding to both of these literatures, this article wants to contribute to our understanding of what the new realities of populism mean for Europe's democracies by examining how the electoral success of populist parties affects political trust in the general public and whether and how this effect varies across countries depending on democratic quality, corruption control, and government performance.

Empirically, this study combines ParlGov data (Döring \& Manow, 2018) on the electoral success of populist parties with survey data from the European Social Survey (2002-2016) as well as aggregate data from the Varietiesof-Democracy project (Coppedge et al., 2019) and the World Development Indicators (World Bank, 2018). It models how populist parties winning electoral votes has affected changes in the level of political trust to investigate how political trust has changed in relation to the growing success of populist parties and how democratic quality, corruption control, and government performance have moderated this relationship in 23 European democracies. It finds that, despite them typically being characterized as a danger to democracy, populist parties celebrating electoral successes, at least in the short run, has no detrimental effect on political trust.
On the contrary, levels of political trust appear to even increase after populist parties have gained electoral votes. The analysis finds this increase in political trust to be most pronounced in political systems that lack in democratic quality, struggle with corruption, and deliver only meager government performance, indicating that populist parties may be seen as more of a corrective force in these countries.

\section{The Populist Message and Political Trust}

Populism, as defined by Mudde (2004, p. 543), is "an ideology that considers society to be ultimately separated into two homogeneous and antagonistic groups, 'the pure people' versus 'the corrupt elite,' and which argues that politics should be an expression of the volonté générale (general will) of the people." Both left- and rightwing populist parties are thus united in their criticism of the established democratic procedures, institutions, and political elites (Galston, 2018).

Among other things, populists typically accuse established parties and politicians of not caring about the common people, not being responsive or accountable to ordinary people's demands, and of being incompetent (Mudde, 2004; Sheets, Bos, \& Boomgaarden, 2016). As care, responsiveness, accountability, and competence are core components of what makes a political system-or anyone, for that matter-appear trustworthy (Kasperson, Golding, \& Tuler, 1992; van der Meer, 2010), these populist messages are bound to undermine citizens' trust in the political system. In line with these expectations, prior research has demonstrated already that populist messages lead to more negative views of the political system among supporters of populist parties (Rooduijn, van der Brug, de Lange, \& Parlevliet, 2017) and that populist voters are less trusting of the political system than voters of other parties (Dahlberg \& Linde, 2017; Söderlund \& Kestilä-Kekkonen, 2009). A number of results further indicate that the reception of antisystem messages can damage citizens' attitudes towards the political system (Hameleers, Bos, \& de Vreese, 2018; Sheets et al., 2016). At the same time, disenchantment with and cynicism about the political system has been identified as a major driver of populist parties' electoral success (Cutts, Ford, \& Goodwin, 2011; Hooghe et al., 2011; Rooduijn, 2018). The relationship between populist parties and citizens' attitudes towards the political system thus seems to be a mutually reinforcing, negative one: disenchantment with politics furthers populist parties' success and populist parties further disenchantment with politics.

\section{How Populist Party Success May Help Citizens Regain Trust in Broken Systems}

These individual-level correlations would suggest that the rise of populist parties leads to a decline in political trust among citizens in Europe. Yet, as recent studies 
indicate that populist parties entering parliaments and governments may actually increase trust and satisfaction with democracy (Haugsgjerd, 2019), this article argues that there is another mechanism at play when it comes to the effects of populist party success.

Despite their anti-establishment and anti-system platform, populist parties gaining in strength could have a healing effect on political trust. For one, populist parties winning votes and parliamentary seats may make the political system appear more responsive to citizens' demands. With citizens being disaffected with the political system even before populist parties gained in popularity (Norris, 1999; Pharr \& Putnam, 2000)-and potentially fueling populist parties' electoral successes in the first place (Cutts et al., 2011; Schumacher \& Rooduijn, 2013)-, populist parties becoming represented in the political system may help attenuate this disaffection and reconcile citizens with the political system. Previous literature has already discussed the importance of representation for political trust. While the effects of descriptive representation are ambiguous (Cowley, 2014; Gay, 2002; Hinojosa, Fridkin, \& Kittilson, 2017), actual as well as perceived representation of interests can play a crucial role in generating trust in democratic institutions (Cho, 2012; Dunn, 2015; van der Meer \& Dekker, 2011). As the literature demonstrates, it is representation in parliament, not the sheer existence of (populist) parties that drives this effect. For people to feel their voices are being heard and their concerns are being taken seriously by the political system, the political actors actively voicing those concerns-i.e., the populist parties-cannot be seen as operating outside of this system but rather need to be represented in at least some of its core institutions, particularly in parliament. The political system consequently will only appear responsive to citizens' concerns when populist parties have become at least reasonably successful, gaining substantive electoral and parliamentary representation. Populist representation should of course have positive effects especially for outright supporters of populist parties and their ideologies. Nonetheless, even if a majority of citizens may not agree with other aspects, e.g., the radical-right or radical-left parts of their ideology, populist parties entering the political system can make citizens feel like their own concerns about the political system are finally being heard and taken seriously, thereby increasing perceptions of the political system as being caring and accountable, and, consequently, more trustworthy (Ivarsflaten, 2008; Mudde \& Rovira Kaltwasser, 2012). Populist parties could then be perceived as a corrective force helping to right the wrongs of the existing political institutions.

Second, established political parties and politicians responding to the challenge raised by populist parties may also contribute to citizens regaining trust in the political system. In light of populist parties gaining in strength, political discourse in many countries was revitalized, with established parties and other civil society actors emphasizing the advantages of the existing political system and taking a decisively pro-democratic and pro-system stance (e.g., Stanley, 2015; Verbeek \& Zaslove, 2015). Especially for citizens opposed to the radical-right and radical-left ideologies, suddenly being presented with the alternative to the existing political system propagated by right- and left-wing populist parties may help them gain renewed appreciation for the existing liberal democratic system and its institutions. With regard to political participation, Immerzeel and Pickup (2015) find that the emergence of successful right-wing populist parties mobilizes those citizens most opposed to a radical-right populist ideology. In spite of the antisystem message propelled by populist parties, them gaining votes and/or parliamentary seats may thus act as a corrective impulse and eventually increase political trust among the general public. Again, the sheer existence of populist parties is unlikely to spur these effects. For both established parties and citizens opposed to the populists' radical ideologies to rise to the challenge presented by populist parties, they must consider this challenge to be a serious one-which is likely only the case when populists are actually becoming successful. Correspondingly, prior research has shown established parties to react to the populist challenge only after the populists have started gaining traction in national or regional elections (Schumacher \& van Kersbergen, 2016; van Kessel, 2011).

Another way in which populist party success may affect citizens' trust in the political system is through the classical 'winner' effect: Prior research on political trust has demonstrated numerous times that those citizens who voted for a party that ended up being in government or gained in vote shares compared to the previous election express more trust in their country's political institutions (Anderson, Blais, Bowler, Donovan, \& Listhaug, 2005; Anderson \& LoTempio, 2002; Martini \& Quaranta, 2019; van der Meer \& Steenvoorden, 2018). Yet this winner effect should apply only to the supporters of populist parties, not to the general public. Instead, supporters of at least some of the non-populist parties should experience a decline in political trust following populist parties' electoral gains as these usually equal losses for the established parties. Overall, we would expect winner and loser effects to cancel out and consequently not to increase political trust in the general public.

While populist party success may also further the spread of the populist anti-system message and thus fuel distrust in the political system, this effect is probably negligible. With populists typically being exceptionally proficient at making use of social and other digital media to spread their message, we can safely assume that citizens have heard and bought into the populist anti-establishment and anti-system rhetoric long before these parties became successful in the electoral arena (Rooduijn, 2014). In fact, this is likely to be the reason for them winning a sizeable number of votes in the first place (Bos, van der Brug, \& de Vreese, 2010). We would thus still expect populist party success to be followed by an increase in political trust rather than a decrease: 
$\mathrm{H}_{1}$ : Populist party success increases political trust in the general public.

Yet this positive effect of populist parties' success on political trust depends on populist parties being perceived as or even actually acting as a corrective force in the political system. This implies that citizens have to perceive their political system to be in need of correction in the first place. While outright supporters of populist parties may have already fully bought into the populist message of the established political system being 'broken' regardless of how well the system actually works, this is unlikely to be the case for the general public. Despite prior research having shown some disgruntlement with the existing political institutions to be present in every country (Klingemann, 2014; Norris, 1999; Pharr \& Putnam, 2000), the extent to which the political system is in need of repair depends on contextual factors like democratic quality, corruption control, and government performance. All three of these contextual factors have previously been identified as sources of political trust (e.g., Hakhverdian \& Mayne, 2012; van Erkel \& van der Meer, 2016; Wagner, Schneider, \& Halla, 2009); yet, their conditioning effect has seldom been studied.

However, democratic quality, corruption control, and government performance may act as moderating factors on the effect populist parties' success can have on political trust as they determine the extent to which citizens see their democratic system to be in need of repair. If democratic quality is lacking, corruption is rampant, and government performance in the economic, administrative, or other realms is mediocre at best, citizens may long more strongly for an 'outsider' (i.e., a populist party) to enter the political system and tackle those problems. In addition, there is simply more room for improvement in faulty democracies. If democratic quality is already exceptional, corruption virtually eradicated, and government performance on an all-time high, there is little established parties can improve in reaction to the challenge raised by populist parties. In contrast, if democratic quality leaves a lot to be desired, corruption poses a serious problem, or government performance is deficient, established parties may be able to respond to the criticism from populist parties by launching reforms in these realms. We would thus expect the positive effect of populist success on political trust to be most pronounced in those countries where democratic quality is lacking, corruption control is weak, and government performance low:

$\mathrm{H}_{2}$ : Democratic quality mitigates the effect of populist party success on political trust.

$\mathrm{H}_{3}$ : Corruption control mitigates the effect of populist party success on political trust.

$\mathrm{H}_{4}$ : Government performance mitigates the effect of populist party success on political trust.

\section{Data and Measurement}

To examine how the rise of populist parties has affected political trust in European democracies, this study combines individual-level data from the European Social Survey (2002-2016; European Social Survey, 2016) with aggregate-level data from the ParlGov project (1997-2016; Döring \& Manow, 2018), V-Dem (v9; 1997-2016; Coppedge et al., 2019), and the World Development Indicators (1997-2016; World Bank, 2018). It analyzes how changes in populist party vote share relate to changes in political trust.

The dependent variable political trust is measured as trust in three different political institutions: parliament, parties, and politicians. These three institutions are arguably the ones most in focus of populist parties' antiestablishment rhetoric, and the effects of populist party success should thus be most pronounced for trust in these institutions.

For the independent variable populist party success, I calculate the gain in popular vote shares for populist parties from one national parliamentary election to the next based on the ParlGov data. The identification of populist parties relies on the PopuList (Rooduijn et al., 2019). Table 1 lists those parties. Vote shares for all populist parties within a single country and election are added up to arrive at the total vote share for populist parties. Figure 1 gives an overview of the vote shares for populist parties per country over time.

Election results are matched to the ESS data according to the date of the election and the ESS fieldwork period. For example, for ESS round 1 in Austria (fielded between February and September 2003), the relevant election took place on November 24, 2002. If an election took place during the fieldwork period of the ESS, the respective country-round was excluded. This concerns the following countries: Cyprus (round 5), Estonia (round 3), Greece (round 4), Netherlands (rounds 1, 3, and 6), Slovenia (round 2), Sweden (round 7), United Kingdom (round 7). Gains in vote shares are always calculated from one ESS round to the next, so if no election took place in between two ESS rounds, gains in vote shares equals 0 . Likewise, if more than one election took place between two ESS rounds (i.e., when a country skipped one or more ESS rounds or in the case of snap elections), the change in populist vote shares equals the difference between the election taking place closest to the respective ESS round and the election taking place before the previous ESS round.

For the moderating factors, democratic quality is measured using V-Dem's Index of Liberal Democracy, corruption control is measured using V-Dem's Index of Political Corruption (recoded so that high values indicate more corruption control), and government performance is measured in terms of a composite measure combining GDP growth, inflation (consumer prices), and unemployment. These aggregate-level data were allocated according to the year of the ESS round (e.g., 2002 for round 1) in- 
Table 1. Populist parties in European Social Survey (ESS) countries.

\begin{tabular}{|c|c|c|}
\hline & Right-wing populist parties & Left-wing populist parties \\
\hline Austria & Alliance for the Future of Austria; Freedom Party of Austria & - \\
\hline Belgium & Flemish Interest; National Front & - \\
\hline Bulgaria & $\begin{array}{l}\text { Attack; National Front for the Salvation of Bulgaria; } \\
\text { Order, Law and Justice }\end{array}$ & - \\
\hline Cyprus & - & Citizens' Alliance \\
\hline Czechia & $\begin{array}{l}\text { Coalition for Republic; Dawn-National Coalition; } \\
\text { Freedom and Direct Democracy }\end{array}$ & - \\
\hline Denmark & Danish People's Party; Progress Party & - \\
\hline Estonia & Conservative People's Party & - \\
\hline Finland & Finns Party & - \\
\hline France & Front National & France Unbowed \\
\hline Germany & Alternative for Germany & The Left \\
\hline Greece & Popular Orthodox Rally & Democratic Social Movement, Syriza \\
\hline Hungary & $\begin{array}{l}\text { Fidesz-Hungarian Civic Alliance }{ }^{a} \text {; Hungarian Justice and } \\
\text { Life Party for a Better Hungary; Jobbik, the Movement }\end{array}$ & - \\
\hline Iceland & - & - \\
\hline Ireland & - & Sinn Féin \\
\hline Italy & Brothers of Italy; Northern League & - \\
\hline Latvia & - & - \\
\hline Lithuania & - & - \\
\hline Netherlands & Fortuyn List; Party for Freedom & Socialist Party \\
\hline Norway & Progress Party & \\
\hline Poland & Kukiz '15; Law and Justice ${ }^{\text {b; }}$ League of Polish Families & - \\
\hline Portugal & - & - \\
\hline Slovakia & Real Slovak National Party; Slovak National Party & - \\
\hline Slovenia & - & United Left \\
\hline Spain & - & Podemos \\
\hline Sweden & Sweden Democrats & - \\
\hline Switzerland & Swiss People's Party & - \\
\hline United Kingdom & UK Independence Party & - \\
\hline
\end{tabular}

Notes: Includes only countries that were surveyed in at least three ESS rounds. Identification of right-wing and left-wing populist parties based on PopuList (Rooduijn et al., 2019). ${ }^{a}$ since 2002, ${ }^{\text {b }}$ since 2005.

stead of the year(s) the actual fieldwork was done in each country. While this means that data may not be coming from the exact year that fieldwork was done, the offset is reasonably small (maximum 1 year before the fieldwork period). By using the ESS round year, which is typically up to one year ahead of actual fieldwork, the analysis avoids using data from years that have not yet passed when ESS fieldwork was conducted (when fieldwork was conducted in the beginning of the year), as well as having to use data from different years for respondents from the same country in the same ESS round (when fieldwork spanned the turn of the year).

In addition, the models control for competing explanatory variables of political trust. On the individual level, control variables are economic performance evaluations (e.g., Mishler \& Rose, 2001), political interest 


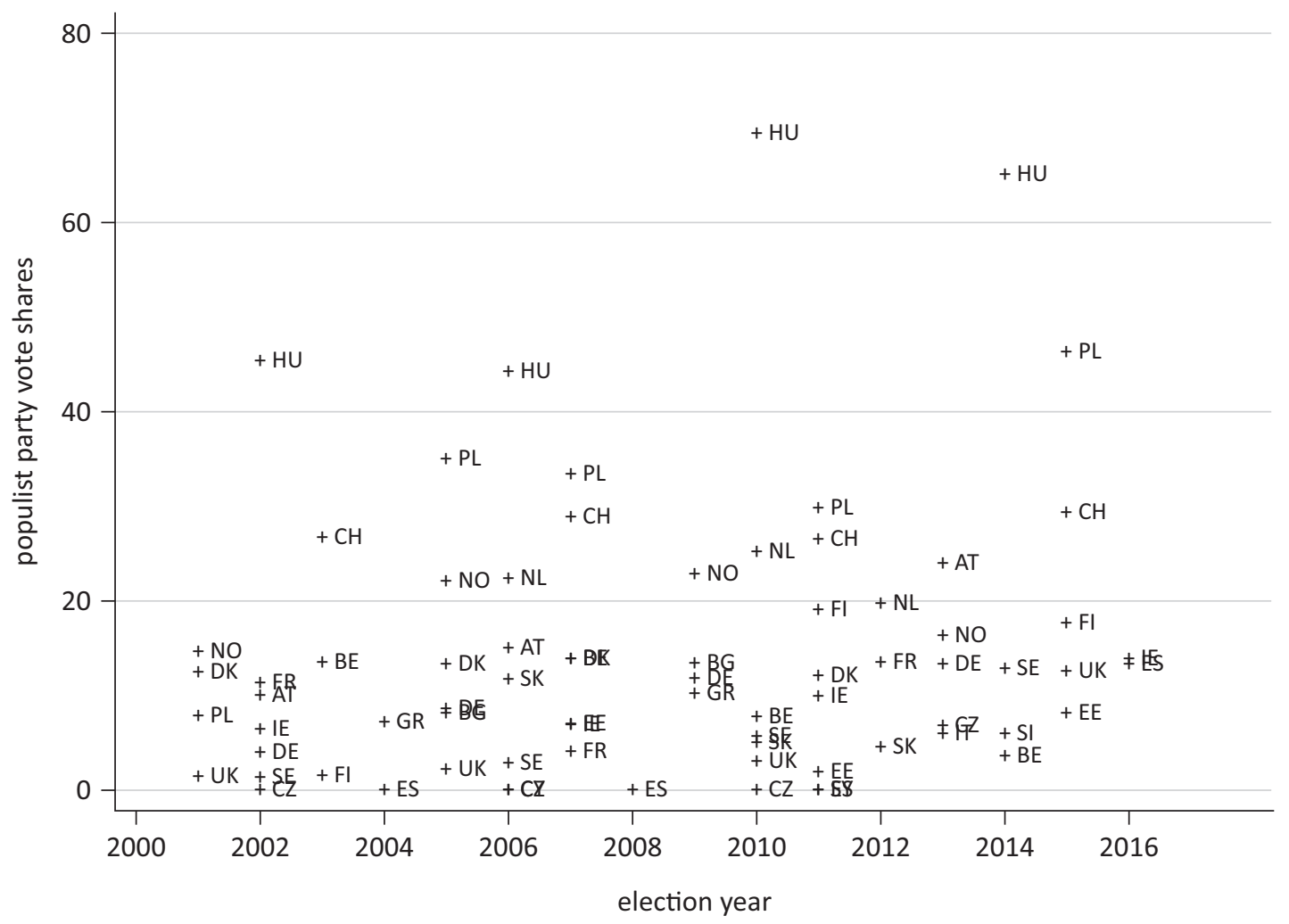

Figure 1. Populist party vote shares per country, 2001-2016. Source: ParlGov (1997-2016; Döring \& Manow, 2018).

(e.g., Lü, 2014), and social trust (e.g., Zmerli \& Newton, 2008). As the analysis aggregates data to the countryround level and uses weighted means for this purpose, standard sociodemographics are not included as control variables. On the macro level, the analysis controls for a country's level of socioeconomic development: logged GDP per capita (PPP; World Bank, 2018) and degree of urbanization (World Bank, 2018).

The analysis includes only countries that were sampled in at least three ESS rounds between 2002 and 2016 and that were rated as democratic (based on V-Dem's Regimes-in-the-World measure; Lührmann, Tannenberg, \& Lindberg, 2018) throughout the entire period (1997-2016; ESS countries that do not match these criteria: Croatia, Luxemburg, Russia, Turkey, and Ukraine). It excludes countries without a successful populist party, i.e., which did not have at least one populist party gain parliamentary seats in at least one election between 1997 and 2016. This applies to Iceland, Lithuania, and Portugal. Robustness checks including these three countries do not yield substantially different results. After excluding country-rounds in which national parliamentary elections took place during the ESS fieldwork period, the data cover 148 country-rounds (130 country-rounds for analyses of trust in political parties; 23 individual countries; Table 2).

For the empirical analysis, all data are aggregated to the country-round level. The models regress changes in political trust (trust in parliament, trust in parties, trust in politicians) from one ESS round to the next on pop- ulist party vote gain. Changes in political trust are calculated as the difference in aggregated levels of trust from one ESS round to the next. As there are no previous data for levels of political trust for the first ESS round fielded in each country, the number of country-rounds drops to 125 (trust in parliament, trust in politicians) and 107 (trust in parties), respectively.

All individual- and system-level control variables are also modeled in terms of changes as compared to the previous ESS round. For the moderating factors democratic quality, corruption, and government performance, on the other hand, I use absolute levels as the extent to which a political system lends itself to populist criticism depends more on its absolute levels of democratic quality, corruption control, and government performance than on changes in these contextual characteristics. In addition, democratic quality and corruption control are unlikely to change dramatically from one ESS round to the next, so for most European democracies there is little within-country variance in democratic quality and corruption control between 2002 and 2016.

\section{Results}

Starting with the main effect of populist party success on political trust, Figure 2 presents the results for trust in parliament, trust in political parties, and trust in politicians. Corroborating the expectations, electoral success of populist parties does not decrease political trust among the general public. In contrast, most empirical 
Table 2. Country-rounds included in analysis.

\begin{tabular}{|c|c|c|c|c|c|c|c|c|}
\hline & 2002 & 2004 & 2006 & 2008 & 2010 & 2012 & 2014 & 2016 \\
\hline Austria & $\bullet$ & $\bullet$ & $\bullet$ & $\mathrm{n} / \mathrm{a}$ & $\mathrm{n} / \mathrm{a}$ & & $\bullet$ & $\bullet$ \\
\hline Belgium & $\bullet$ & $\bullet$ & $\bullet$ & $\bullet$ & $\bullet$ & $\bullet$ & $\bullet$ & $\bullet$ \\
\hline Bulgaria & & & $\bullet$ & $\bullet$ & $\bullet$ & $\bullet$ & & \\
\hline Cyprus & & & $\bullet$ & $\bullet$ & $\bullet$ & $\bullet$ & & \\
\hline Czechia & $\bullet$ & $\bullet$ & & $\bullet$ & $\bullet$ & $\bullet$ & $\bullet$ & $\bullet$ \\
\hline Denmark & $\bullet$ & $\bullet$ & $\bullet$ & $\bullet$ & $\bullet$ & $\bullet$ & $\bullet$ & \\
\hline Estonia & & $\bullet$ & ele & $\bullet$ & $\mathrm{n} / \mathrm{a}$ & $\bullet$ & $\bullet$ & $\bullet$ \\
\hline Finland & $\bullet$ & $\bullet$ & $\bullet$ & $\bullet$ & $\bullet$ & $\bullet$ & $\bullet$ & $\bullet$ \\
\hline France & $\bullet$ & $\bullet$ & $\bullet$ & $\bullet$ & $\bullet$ & $\bullet$ & $\bullet$ & $\bullet$ \\
\hline Germany & $\bullet$ & $\bullet$ & $\bullet$ & $\bullet$ & $\bullet$ & $\bullet$ & $\bullet$ & $\bullet$ \\
\hline Greece & $\bullet$ & $\bullet$ & & ele & $\bullet$ & & & \\
\hline Hungary & $\bullet$ & $\bullet$ & $\bullet$ & $\bullet$ & $\bullet$ & $\bullet$ & $\bullet$ & $\bullet$ \\
\hline Ireland & $\bullet$ & $\bullet$ & $\bullet$ & $\bullet$ & $\bullet$ & $\bullet$ & $\bullet$ & $\bullet$ \\
\hline Italy & $\bullet$ & $\mathrm{n} / \mathrm{a}$ & & & & $\bullet$ & & $\bullet$ \\
\hline Netherlands & ele & $\bullet$ & ele & $\bullet$ & $\bullet$ & ele & $\bullet$ & $\bullet$ \\
\hline Norway & $\bullet$ & $\bullet$ & $\bullet$ & $\bullet$ & $\bullet$ & $\bullet$ & $\bullet$ & $\bullet$ \\
\hline Poland & $\bullet$ & $\bullet$ & $\bullet$ & $\bullet$ & $\bullet$ & $\bullet$ & $\bullet$ & $\bullet$ \\
\hline Slovakia & & $\bullet$ & $\bullet$ & $\bullet$ & $\bullet$ & $\bullet$ & & \\
\hline Slovenia & $\bullet$ & $\bullet$ & $\bullet$ & $\bullet$ & $\bullet$ & $\bullet$ & $\bullet$ & $\bullet$ \\
\hline Spain & $\bullet$ & $\bullet$ & $\bullet$ & $\bullet$ & $\bullet$ & $\bullet$ & $\bullet$ & $\bullet$ \\
\hline Sweden & $\bullet$ & $\bullet$ & $\bullet$ & $\bullet$ & $\bullet$ & $\bullet$ & ele & $\bullet$ \\
\hline Switzerland & $\bullet$ & $\bullet$ & $\bullet$ & $\bullet$ & $\bullet$ & $\bullet$ & $\bullet$ & $\bullet$ \\
\hline United Kingdom & $\bullet$ & $\bullet$ & $\bullet$ & $\bullet$ & $\bullet$ & $\bullet$ & ele & $\bullet$ \\
\hline
\end{tabular}

Notes: $\bullet$ = country-round included, $\mathrm{n} / \mathrm{a}=$ survey data is not included in cumulative ESS file or fieldwork dates were not recorded, ele $=$ country-round was excluded from analysis because election took place during fieldwork period.

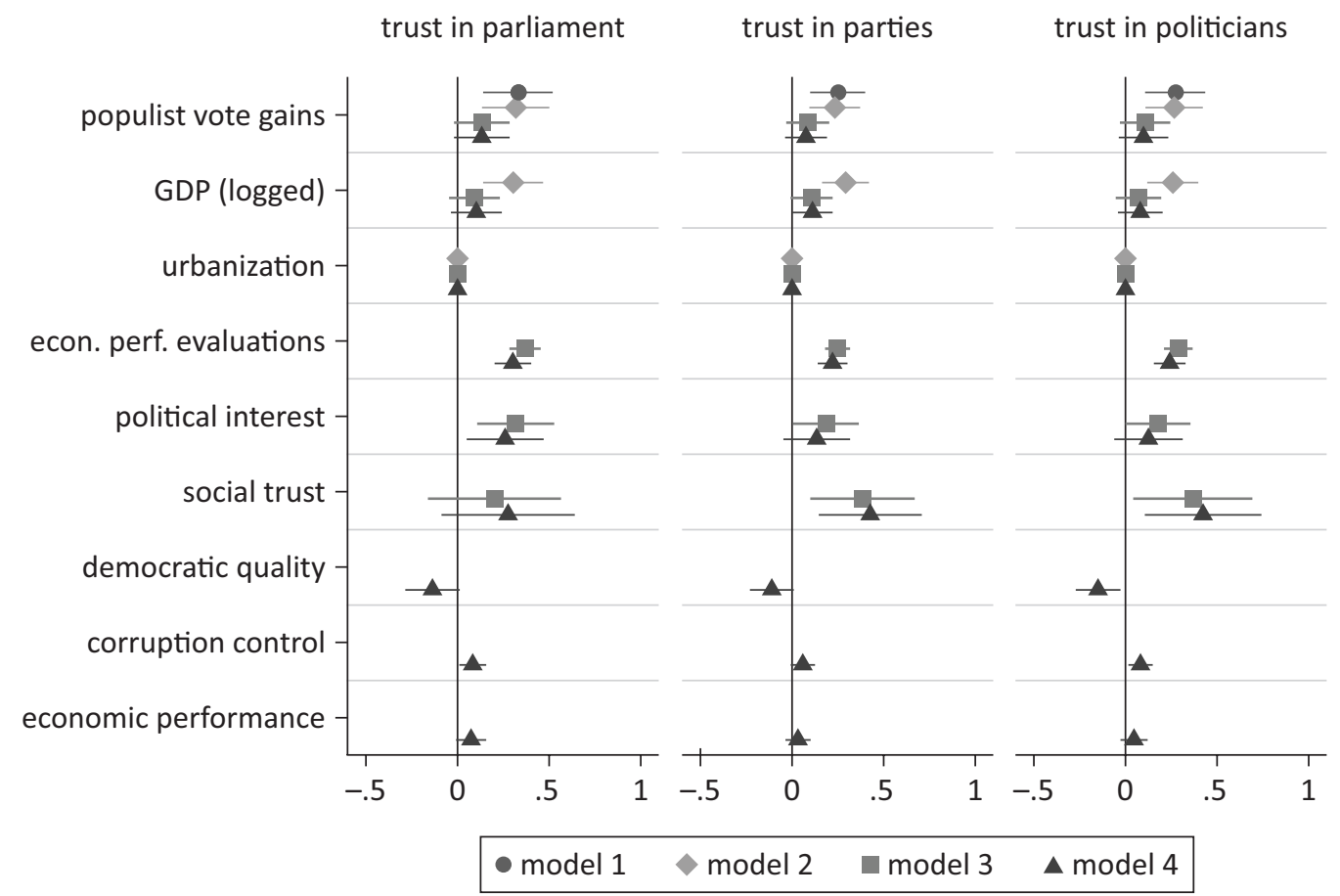

Figure 2. Main effects of populist party success on political trust. Notes: Coefficients and $95 \%$ confidence intervals. $\mathrm{N}=125$ (trust in parliament, trust in politicians)/ $\mathrm{N}=107$ (trust in parties). Model 1: bivariate. Model 2: including macro controls. Model 3: including macro and micro controls. Model 4: including macro and micro controls plus democratic quality, corruption control, and economic performance. Sources: European Social Survey 2002-2016 (European Social Survey, 2016); ParlGov 1997-2016 (Döring \& Manow, 2018); V-Dem v9 (Coppedge et al., 2019); World Development Indicators 2002-2016 (World Bank, 2018). 
models yield a significant positive effect of populist party success on citizens' trust in both parliament, political parties, and politicians. The results thus support the hypothesis that populist parties' success may act as a corrective force to the existing political system $\left(\mathrm{H}_{1}\right)$. Whether this is due to citizens seeing populist parties themselves as being this corrective force and their sheer presence in political institutions as making the political system more caring and accountable or rather the consequence of established parties and citizens responding to the populist challenge with their own pro-system campaign cannot be determined based on the present data. We can, however, assert that levels of political trust tend to increase rather than decrease in the wake of populist party success. This is the case for both the populist electorate and the non-populist electorate, indicating that this is a general effect rather than a mere 'winner' effect driven by populist party supporters (re-)gaining trust in the political system (cf. Supplementary File).
Going beyond the main effect of populist party success on political trust, we expected this effect to be conditional on contextual characteristics like democratic quality, corruption control, and government performance. Figure 3 to Figure 5 graph these conditional effects. Beginning with the moderating effect of democratic quality, Figure 3 confirms that populist party success has different effects in countries with different levels of democratic quality. Corresponding to the theoretical conjecture $\left(\mathrm{H}_{2}\right)$, the effect of populist party success weakens for countries with a higher level of democratic quality. As we would have expected based on the corrective-force argument, for countries with a comparatively low level of democratic quality, populist parties becoming more successful in national parliamentary elections has a significant positive effect on political trust among the general public. Citizens in these countries seem to extend more trust to both parliament, political parties, and politicians following electoral successes of populist parties. For all
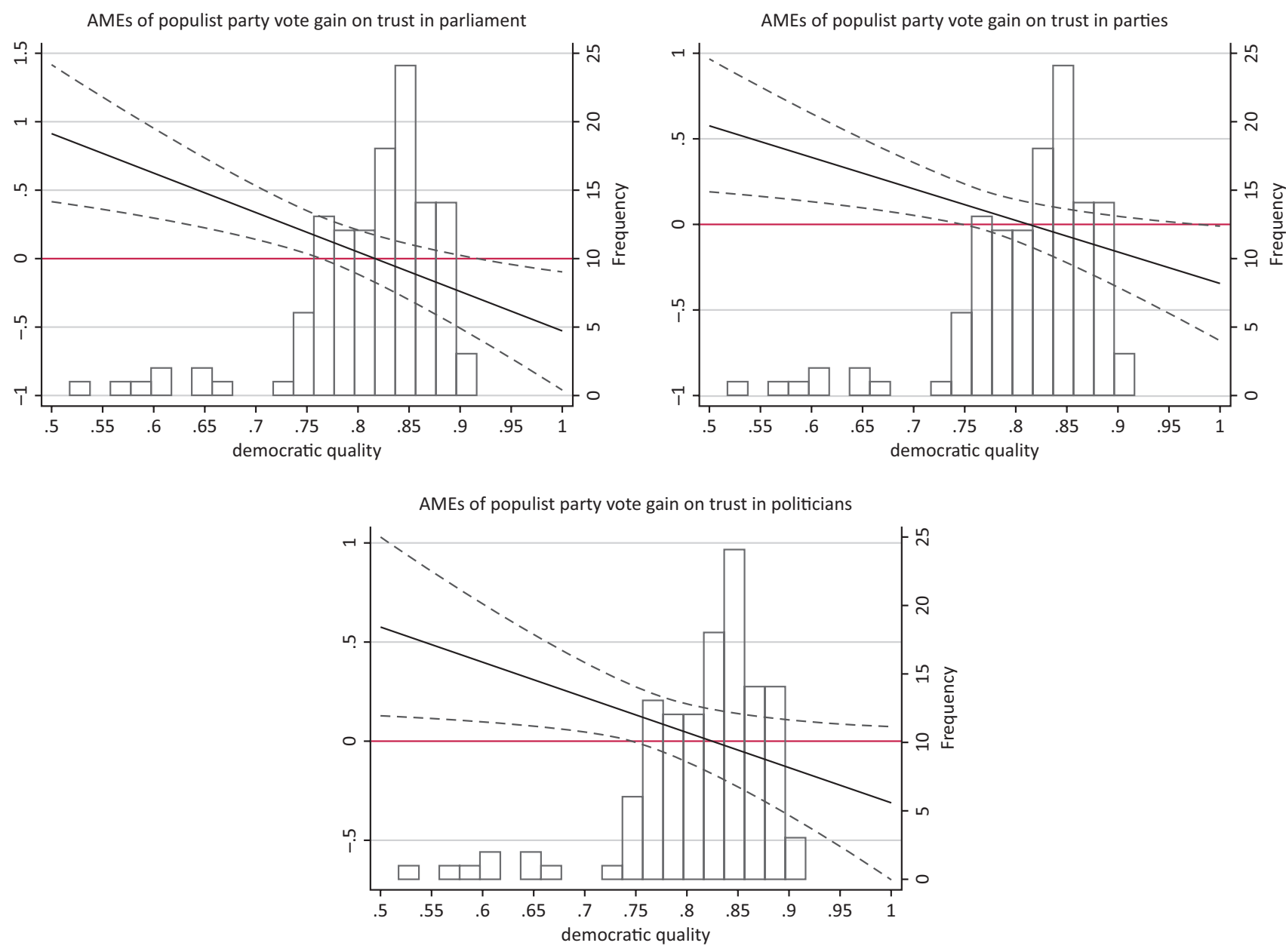

Figure 3. Conditional effects of populist success on political trust: democratic quality. Notes: Unstandardized estimates and $95 \%$ confidence intervals of conditional effect for varying degrees of democratic quality (0.05 scale points intervals). Control variables: (changes in) perceptions of economic performance, political interest, social trust, GPD/capita, urbanization; (levels of) corruption control, economic performance. $\mathrm{N}=125$ (trust in parliament, trust in politicians)/ $\mathrm{N}=107$ (trust in parties). Sources: European Social Survey 2002-2016 (European Social Survey, 2016); ParlGov 1997-2016 (Döring \& Manow, 2018); V-Dem v9 (Coppedge et al., 2019); World Development Indicators 2002-2016 (World Bank, 2018). 
three institutions, this effect on citizen trust gradually decreases with increasing democratic quality and vanishes completely for high-quality liberal democracies, suggesting that citizens may not perceive there to be much room for improvement of the existing political system.

Turning to the moderating effect of corruption control, Figure 4 also shows results in line with the correctiveforce argument. Instead of populist party success having a more detrimental effect on political trust in countries with high levels of corruption-i.e., countries that we would expect to lend themselves more easily to populist criticism - it is precisely these countries where populist success substantially increases political trust among the general public. This again points to citizens perceiving populist parties as a corrective force that can help tackle the problems-in this case corruption-of the existing political system. Like for democratic quality, populist party success has no effect on political trust at all in those countries where there is little room for improvement.
The picture looks virtually the same for the moderating effect of economic performance (Figure 5). Yet again, the effect of populist parties' vote gains on trust in parliament, trust in political parties, and trust in politicians alike are conditional on the level of economic performance in a given country, and the interaction effect points to populist parties being seen as more of a corrective force in countries with lacking government performance. Populist parties receiving more votes in national parliamentary elections has a significant positive effect on political trust in countries with a comparatively low level of economic performance. In countries with high levels of economic performance, in contrast, populist party success does not have any effect on political trust among the general public at all. All results remain robust to alternative model specifications (including country dummies, including countries without a successful populist party, including populists-in-government dummy, including new-democracies dummy) and operationaliza-
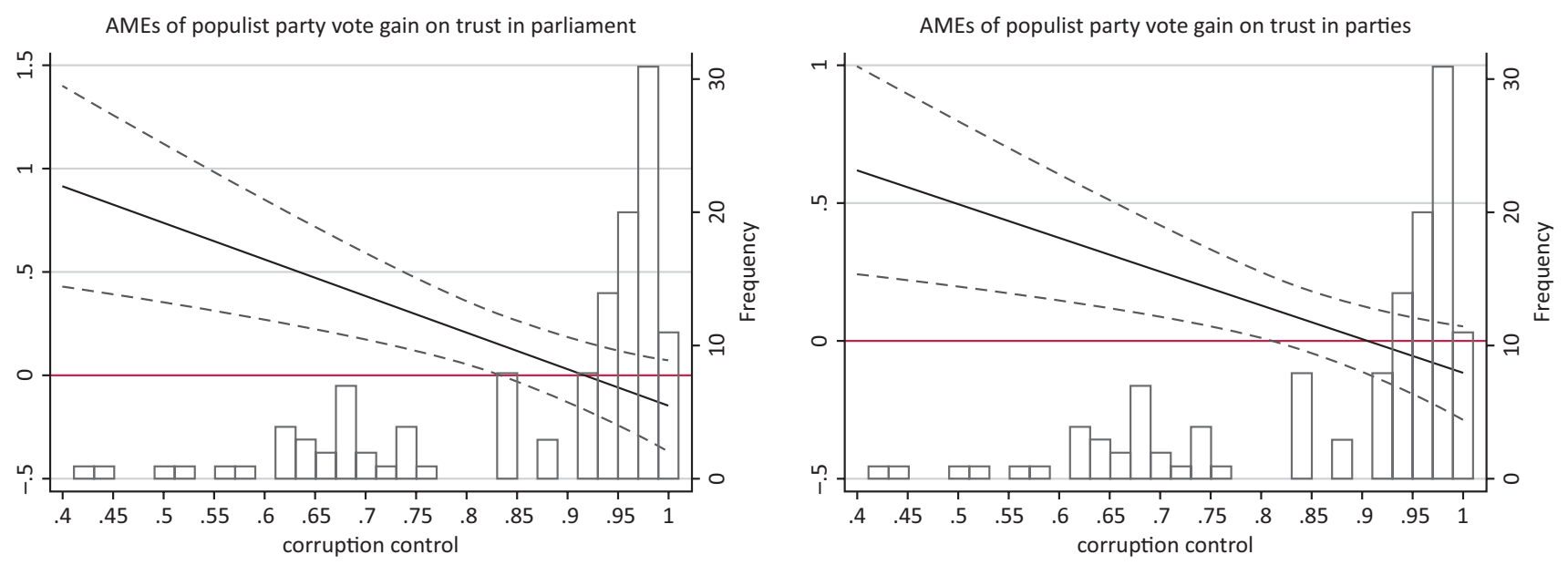

AMEs of populist party vote gain on trust in politicians

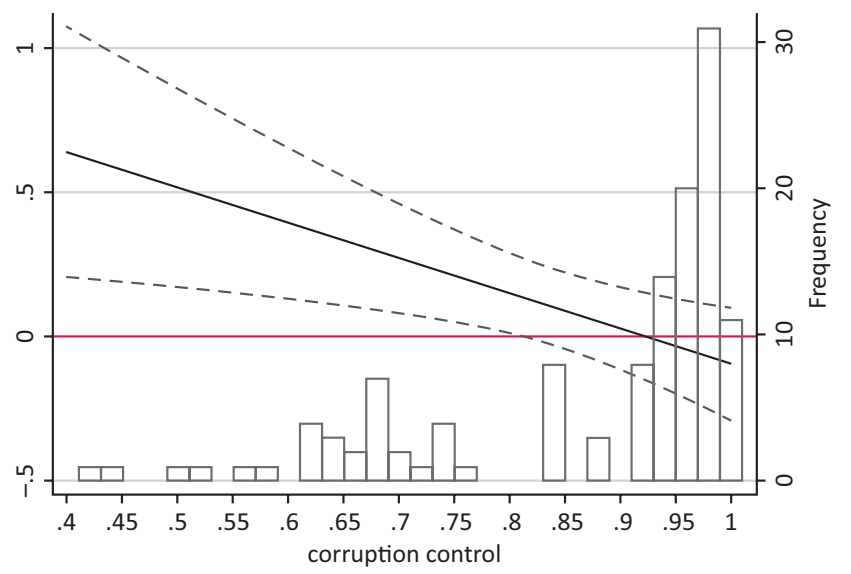

Figure 4. Conditional effects of populist success on political trust: corruption control. Notes: Unstandardized estimates and $95 \%$ confidence intervals of conditional effect for varying degrees of corruption ( 0.05 scale points intervals). Control variables: (changes in) perceptions of economic performance, political interest, social trust, GPD/capita, urbanization; (levels of) democratic quality, economic performance. $\mathrm{N}=125$ (trust in parliament, trust in politicians)/ $\mathrm{N}=107$ (trust in parties). Sources: European Social Survey 2002-2016 (European Social Survey, 2016); ParlGov 1997-2016 (Döring \& Manow, 2018); V-Dem v9 (Coppedge et al., 2019); World Development Indicators 2002-2016 (World Bank, 2018). 

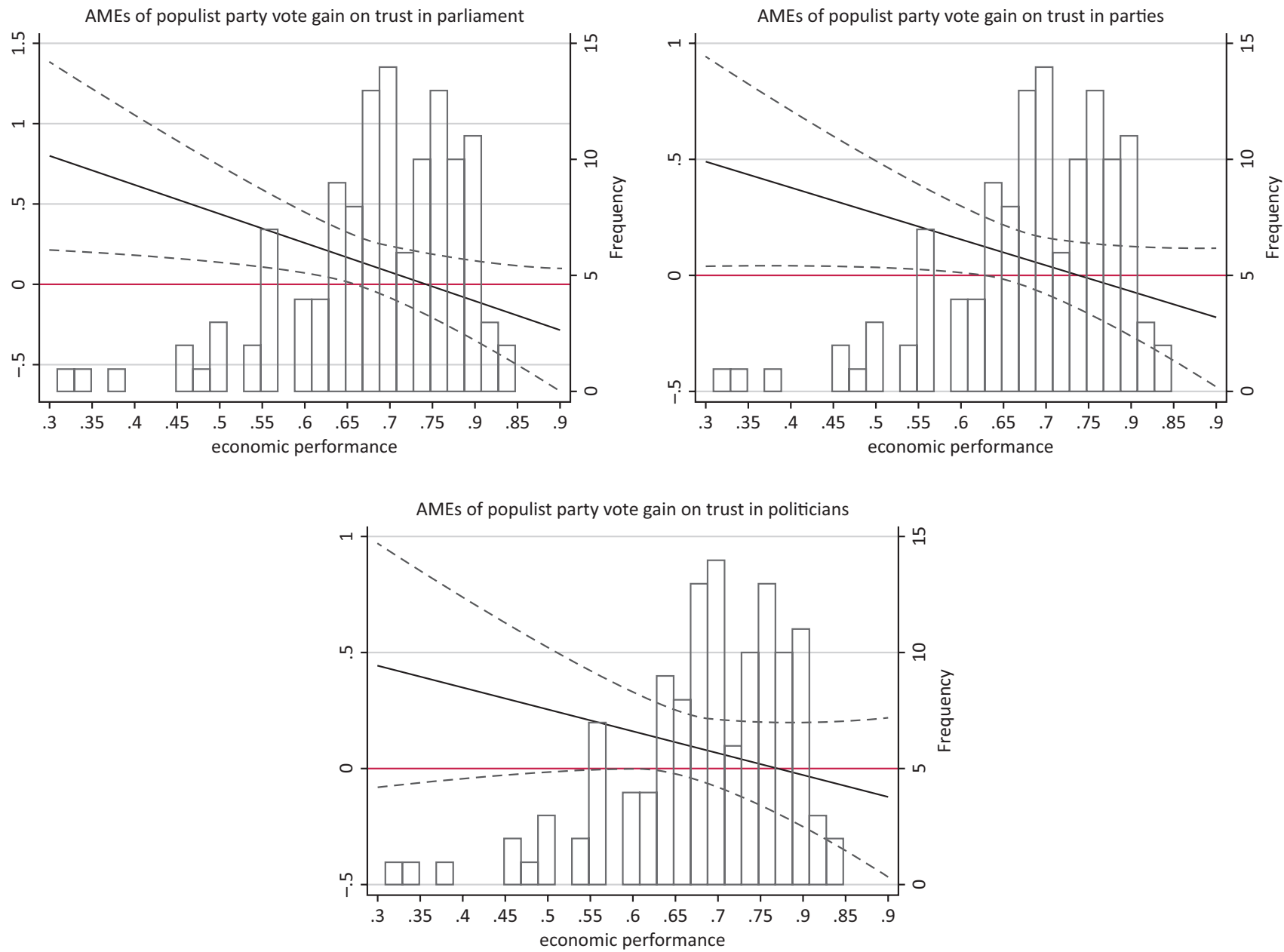

Figure 5. Conditional effects of populist success on political trust: economic performance. Notes: Unstandardized estimates and $95 \%$ confidence intervals of conditional effect for varying degrees of economic performance $(0.05$ scale points intervals). Control variables: (changes in) perceptions of economic performance, political interest, social trust, GPD/capita, urbanization; (levels of) democratic quality, corruption control. $\mathrm{N}=125$ (trust in parliament, trust in politicians)/ $\mathrm{N}=107$ (trust in parties). Sources: European Social Survey 2002-2016 (European Social Survey, 2016); ParlGov 1997-2016 (Döring \& Manow, 2018); V-Dem v9 (Coppedge et al., 2019); World Development Indicators 2002-2016 (World Bank, 2018).

tions of the dependent (as satisfaction with democracy) and independent (as gains in parliamentary seats) variables. While the results are clearly stronger for right-wing populist parties, they tend to point in the same direction when looking at the much smaller subset of left-wing populist parties only as well. The same is the case when comparing the populist to the non-populist electorates: while the effects are somewhat stronger for the populist electorate, they are still present in the non-populist electorate (cf. Supplementary File).

\section{Conclusion}

In light of the most recent wave of populism across Europe and the concerns voiced about this rise of populism, this contribution set out to explore how the electoral success of populist parties affects citizens' trust in the political system. Regarding this macro-level relationship, it suggested that, despite previous findings evidencing a negative relationship between populist party sup- port and political trust on the individual level, the electoral success of populist parties may still increase political trust among the general public. It argued that populist parties may be perceived as a corrective force finally giving voice to and tackling concerns about the political system that had long been prevalent among citizens. Reasoning that there needs to be at least some room for improvement for this corrective-force effect to come into play, it further introduced democratic quality, corruption control, and government performance as contextual factors conditioning the relationship between populist party success and political trust.

Combining survey data from the European Social Survey (2002-2016) with election data from the ParlGov project (1997-2016) and aggregate data on the contextual characteristics from V-Dem and the World Development Indicators for 23 European democracies, it found that populist party success indeed has an overall positive effect on levels of political trust among the general public. As far as the contextual characteristics 
were concerned, populist party success had the most pronounced positive effect on political trust in countries with comparatively low levels of democratic quality, corruption control, and government performance. For countries with very high levels of democratic quality, corruption control, and government performance, populist parties gaining votes or parliamentary seats did not affect political trust at all. These results corroborate the corrective-force perspective: apparently, the perceived and/or actual corrective effect of populist parties entering the political stage outweighs their anti-establishment and anti-system message in the eyes of citizens at least in the short run. Even though the present study cannot determine whether this effect will be a long-lasting one, its core findings add to and qualify both the theoretical and empirical assumptions of the bulk of the populism literature, which considers populism to have unequivocally negative consequences for democracy (e.g., Galston, 2018; Müller, 2016; Pappas, 2019; Puddington \& Roylance, 2017), instead lending support to more balanced assessments (Mudde \& Rovira Kaltwasser, 2012). In particular, they contradict previous individual-level results that could be interpreted as suggesting a vicious circle of political distrust and support for populist parties (Cutts et al., 2011; Dahlberg \& Linde, 2017; Hooghe et al., 2011; Rooduijn, 2018; Söderlund \& Kestilä-Kekkonen, 2009) and underscore that we need to be careful not to commit individualistic fallacies when discussing the consequences of populism.

Based on the findings as well as limitations of this study, three main questions may warrant further investigation. For one, future research could make use of panel data to examine whether different groups of citizense.g., supporters of populist parties vs. non-supporters of populist parties-react differently to populist party success, and whether populist party success causes further polarization of the general public. The use of panel data would also present an opportunity to dig deeper into the dynamics of potential winner and loser effects among supporters of populist and supporters of nonpopulist parties, which could only be explored to a very limited extent here. It would, second, be fruitful to analyze how established parties' reactions to the populist challenge condition the effect populist party success has on political trust. For instance, does the inclusion of populists in the political process, e.g., through coalition governments, further gains in political trust by appeasing citizens committed to the populist narrative or does it rather serve to alienate citizens who oppose the populists and/or their radical-right or radical-left ideologies? Finally, and most importantly, we need to study the longterm effects of populist party success. Can the representation of populist parties within the political system contribute to stabilizing political trust or are the positive effects only short-term, with citizens quickly becoming disillusioned when populists start pushing their radical-right or radical-left agendas and/or disappointed by the newcomers not actually bringing about the desired changes to the political system? Given these limitations, the findings presented here can only be a first indication as to how the new realities of populist party success may affect political systems across Europe. At their present stage, they may warrant some cautious optimism. While there are many good reasons to be wary of the rise of populist parties, for political trust-and thereby for the stability of democracy-, these newcomers to the political stage, at least for now, seem to be less detrimental than we may have thought.

\section{Acknowledgments}

I greatly appreciate the provision of data by the European Social Survey, ParlGov, the Varieties-of-Democracy Project, and the World Bank. I would like to thank the participants of the American Political Science Association (APSA) Annual Meeting 2019 in Washington and the EUROLAB Authors' Conference 2019 in Cologne, especially Sandra Grahn, Sergio Martini, Pippa Norris, and Mario Quaranta, as well as Nils Jungmann, Antonia May, Anne-Kathrin Stroppe, and Katharina Werhan for their valuable comments on earlier versions of this article. I am also grateful to three anonymous reviewers as well as Jonas Linde and Heidi Schulze for their constructive criticism and suggestions.

\section{Conflict of Interests}

The author declares no conflict of interests.

\section{Supplementary Material}

Supplementary material for this article is available online in the format provided by the author (unedited).

\section{References}

Anderson, C. J., Blais, A., Bowler, S., Donovan, T., \& Listhaug, O. (2005). Losers' consent: Elections and democratic legitimacy. Oxford: Oxford University Press.

Anderson, C. J., \& LoTempio, A. J. (2002). Winning, losing and political trust in America. British Journal of Political Science, 32(2), 335-351. https://doi.org/10.1017/ S0007123402000133

Biard, B., Bernhard, L., \& Betz, H.-G. (Eds.). (2019). Do they make a difference? The policy influence of radical right populist parties in Western Europe. Lanham, MD: Rowman \& Littlefield.

Bos, L., van der Brug, W., \& de Vreese, C. (2010). Media coverage of right-wing populist leaders. Communications, 35(2), 135. https://doi.org/10.1515/comm. 2010.008

Cho, W. (2012). Accountability or representation? How electoral systems promote public trust in African legislatures. Governance, 25(4), 617-637. https://doi. org/10.1111/j.1468--0491.2012.01598.x 
Coppedge, M., Gerring, J., Knutsen, C. H., Lindberg, S. I., Teorell, J., Altman, D., . . Ziblatt, D. (2019). V-Dem country-year dataset $v 9$ [Data set]. https://doi.org/ 10.23696/vdemcy19

Cowley, P. (2014). Descriptive representation and political trust: A quasi-natural experiment utilising ignorance. The Journal of Legislative Studies, 20(4), 573-587. https://doi.org/10.1080/ 13572334.2014.937121

Cutts, D., Ford, R., \& Goodwin, M. J. (2011). Antiimmigrant, politically disaffected or still racist after all? Examining the attitudinal drivers of extreme right support in Britain in the 2009 European elections. European Journal of Political Research, 50(3), 418-440. https://doi.org/10.1111/j.1475--6765.2010.01936.x

Dahlberg, S., \& Linde, J. (2017). The dynamics of the winner-loser gap in satisfaction with democracy: Evidence from a Swedish citizen panel. International Political Science Review, 38(5), 625-641. https://doi. org/10.1177/0192512116649279

Döring, H., \& Manow, P. (2018). Parliaments and governments database (ParlGov): Information on parties, elections and cabinets in modern democracies. Stable version. Retrieved from http://www.parlgov.org

Doyle, D. (2011). The legitimacy of political institutions. Comparative Political Studies, 44(11), 1447-1473. https://doi.org/10.1177/0010414011407469

Dunn, K. (2015). Voice, representation and trust in parliament. Acta Politica, 50(2), 171-192. https://doi.org/ 10.1057/ap.2014.15

European Social Survey. (2016). Cumulative round 1-8 data. NSD-Norwegian Centre for Research Data, Norway-Data archive and distributor of ESS data for ESS ERIC. Retrieved from http://www. europeansocialsurvey.org

Galston, W. A. (2018). The populist challenge to liberal democracy. Journal of Democracy, 29(2), 5-19. https://doi.org/10.1353/jod.2018.0020

Gay, C. (2002). Spirals of trust? The effect of descriptive representation on the relationship between citizens and their government. American Journal of Political Science, 46(4), 717-732. https://doi.org/10.2307/ 3088429

Hakhverdian, A., \& Mayne, Q. (2012). Institutional trust, education, and corruption: A micro-macro interactive approach. The Journal of Politics, 74(3), 739-750. https://doi.org/10.1017/S0022381612000412

Hameleers, M., Bos, L., \& de Vreese, C. (2018). Framing blame: Toward a better understanding of the effects of populist communication on populist party preferences. Journal of Elections, Public Opinion and Parties, 28(3), 380-398. https://doi.org/10.1080/ 17457289.2017.1407326

Haugsgjerd, A. (2019). Moderation or radicalisation? How executive power affects right-wing populists' satisfaction with democracy. Electoral Studies, 57, 31-45. https://doi.org/10.1016/j.electstud.2018.09. 008
Hinojosa, M., Fridkin, K. L., \& Kittilson, M. C. (2017). The impact of descriptive representation on "persistent" gender gaps: Political engagement and political trust in Uruguay. Politics, Groups, and Identities, 5(3), 435-453. https://doi.org/10.1080/21565503. 2017.1330215

Hooghe, M., Marien, S., \& Pauwels, T. (2011). Where do distrusting voters turn if there is no viable exit or voice option? The impact of political trust on electoral behaviour in the Belgian regional elections of June 2009. Government and Opposition, 46(2), 245-273. https://doi.org/10.1111/j.1477--7053. 2010.01338.x

Immerzeel, T., \& Pickup, M. (2015). Populist radical right parties mobilizing 'the people'? The role of populist radical right success in voter turnout. Electoral Studies, 40, 347-360. https://doi.org/10.1016/ j.electstud.2015.10.007

Ivarsflaten, E. (2008). What unites right-wing populists in Western Europe? Comparative Political Studies, 41(1), 3-23. https://doi.org/10.1177/ 0010414006294168

Kasperson, R. E., Golding, D., \& Tuler, S. (1992). Social distrust as a factor in siting hazardous facilities and communicating risks. Journal of Social Issues, 48(4), 161-187. https://doi.org/10.1111/ j.1540--4560.1992.tb01950.x

Klingemann, H.-D. (2014). Dissatisfied democrats: Democratic maturation in old and new democracies. In R. J. Dalton \& C. Welzel (Eds.), The civic culture transformed: From allegiant to assertive citizens (pp. 116-157). New York, NY: Cambridge University Press.

Lü, X. (2014). Social policy and regime legitimacy: The effects of education reform in China. American Political Science Review, 108(2), 423-437. https://doi.org/ 10.1017/S0003055414000124

Lührmann, A., Tannenberg, M., \& Lindberg, S. I. (2018). Regimes of the World (RoW): Opening new avenues for the comparative study of political regimes. Politics and Governance, 6(1), 60-77. https://doi.org/ 10.17645/pag.v6i1.1214

Martini, S., \& Quaranta, M. (2019). Political support among winners and losers: Within- and betweencountry effects of structure, process and performance in Europe. European Journal of Political Research, 58(1), 341-361. https://doi.org/10.1111/ 1475-6765.12284

Martini, S., \& Quaranta, M. (2020). Citizens and democracy in Europe: Context, changes and political support. Cham: Palgrave Macmillan.

Mishler, W., \& Rose, R. (2001). What are the origins of political trust? Testing institutional and cultural theories in post-communist societies. Comparative Political Studies, 34(1), 30-62.

Mudde, C. (2004). The populist zeitgeist. Government and Opposition, 39(4), 541-563. https://doi.org/ 10.1111/j.1477-7053.2004.00135.x

Mudde, C., \& Rovira Kaltwasser, C. (Eds.). (2012). Pop- 
ulism in Europe and the Americas: Threat or corrective for democracy? New York: Cambridge University Press.

Müller, J.-W. (2016). What is populism? Philadelphia, PA: University of Pennsylvania Press.

Norris, P. (Ed.). (1999). Critical citizens: Global support for democratic governance. Oxford: Oxford University Press.

Pappas, T. S. (2019). Populism and liberal democracy: $A$ comparative and theoretical analysis. Oxford: Oxford University Press.

Pharr, S. J., \& Putnam, R. D. (Eds.). (2000). Disaffected democracies: What's troubling the trilateral countries? Princeton, NJ: Princeton University Press.

Puddington, A., \& Roylance, T. (2017). The dual threat of populists and autocrats. Journal of Democracy, 28(2), 105-119. https://doi.org/10.1353/jod.2017.0028

Rooduijn, M. (2014). The mesmerising message: The diffusion of populism in public debates in Western European media. Political Studies, 62(4), 726-744. https://doi.org/10.1111/1467--9248.12074

Rooduijn, M. (2018). What unites the voter bases of populist parties? Comparing the electorates of 15 populist parties. European Political Science Review, 10(3), 351-368. https://doi.org/10.1017/ S1755773917000145

Rooduijn, M., van der Brug, W., de Lange, S. L., \& Parlevliet, J. (2017). Persuasive populism? Estimating the effect of populist messages on political cynicism. Politics and Governance, 5(4), 136. https://doi.org/ 10.17645/pag.v5i4.1124

Rooduijn, M., van Kessel, S., Froio, C., Pirro, A., de Lange, S., Halikiopoulou, D., . . . Taggart, P. (2019). The PopuList: An overview of populist, far right, far left and Eurosceptic parties in Europe [Data set]. Retrieved from http://popu-list.org

Schumacher, G., \& Rooduijn, M. (2013). Sympathy for the 'devil'? Voting for populists in the 2006 and 2010 Dutch general elections. Electoral Studies, 32(1), 124-133. https://doi.org/10.1016/j.electstud. 2012.11.003

Schumacher, G., \& van Kersbergen, K. (2016). Do mainstream parties adapt to the welfare chauvinism of populist parties? Party Politics, 22(3), 300-312. https://doi.org/10.1177/1354068814549345

Sheets, P., Bos, L., \& Boomgaarden, H. G. (2016). Media cues and citizen support for right-wing populist parties. International Journal of Public Opinion Research, 28(3), 307-330. https://doi.org/10.1093/ ijpor/edv014

Söderlund, P., \& Kestilä-Kekkonen, E. (2009). Dark side of party identification? An empirical study of political trust among radical right-wing voters. Journal of Elections, Public Opinion and Parties, 19(2), 159-181. https://doi.org/10.1080/17457280902799014
Stanley, B. (2015). Confrontation by default and confrontation by design: Strategic and institutional responses to poland's populist coalition government. Democratization, 23(2), 263-282. https://doi.org/ 10.1080/13510347.2015.1058782

van der Meer, T. W. G. (2010). In what we trust? A multi-level study into trust in parliament as an evaluation of state characteristics. International Review of Administrative Sciences, 76(3), 517-536. https:// doi.org/10.1177/0020852310372450

van der Meer, T. W. G., \& Dekker, P. (2011). Trustworthy states, trusting citizens? A multilevel study into objective and subjective determinants of political trust. In S. Zmerli \& M. Hooghe (Eds.), Political trust: Why context matters (pp. 95-116). Colchester: ECPR Press.

van der Meer, T. W. G., \& Steenvoorden, E. H. (2018). Going back to the well: A panel study into the election boost of political support among electoral winners and losers. Electoral Studies, 55, 40-53. https:// doi.org/10.1016/j.electstud.2018.06.007

van Erkel, P. F. A., \& van der Meer, T. W. G. (2016). Macroeconomic performance, political trust and the great recession: A multilevel analysis of the effects of within-country fluctuations in macroeconomic performance on political trust in 15 EU countries, 1999-2011. European Journal of Political Research, 55(1), 177-197. https://doi.org/10.1111/1475-6765. 12115

van Kessel, S. (2011). Explaining the electoral performance of populist parties: The Netherlands as a case study. Perspectives on European Politics and Society, 12(1), 68-88. https://doi.org/10.1080/ 15705854.2011.546148

Verbeek, B., \& Zaslove, A. (2015). Italy: A case of mutating populism? Democratization, 23(2), 304-323. https:// doi.org/10.1080/13510347.2015.1076213

Wagner, A. F., Schneider, F., \& Halla, M. (2009). The quality of institutions and satisfaction with democracy in Western Europe-A panel analysis. European Journal of Political Economy, 25(1), 30-41. https://doi.org/ 10.1016/j.ejpoleco.2008.08.001

Werts, H., Scheepers, P., \& Lubbers, M. (2012). Euroscepticism and radical right-wing voting in Europe, 2002-2008: Social cleavages, socio-political attitudes and contextual characteristics determining voting for the radical right. European Union Politics, 14(2), 183-205. https://doi.org/10.1177/ 1465116512469287

World Bank. (2018). World development indicators, 1960-2017 [Data set]. Retrieved from http://data. worldbank.org/data-catalog/world-developmentindicators

Zmerli, S., \& Newton, K. (2008). Social trust and attitudes toward democracy. Public Opinion Quarterly, 72(4), 706-724. https://doi.org/10.1093/poq/nfn054 


\section{About the Author}

Marlene Mauk is a Research Associate in political science at GESIS-Leibniz Institute for the Social Sciences, Cologne. She holds a PhD in Comparative Politics from Mainz University. Her research interests lie in the field of political culture, with a focus on the comparison between democracies and autocracies; among other topics, she studies political trust and its sources, political value orientations, and various aspects of democratic quality. She is the author of Citizen Support for Democratic and Autocratic Regimes (2020, Oxford University Press). 